\title{
ASESMEN TERPADU DALAM RANGKA MENDUKUNG KEBIJAKAN REHABILITASI PENYALAH GUNA NARKOBA
}

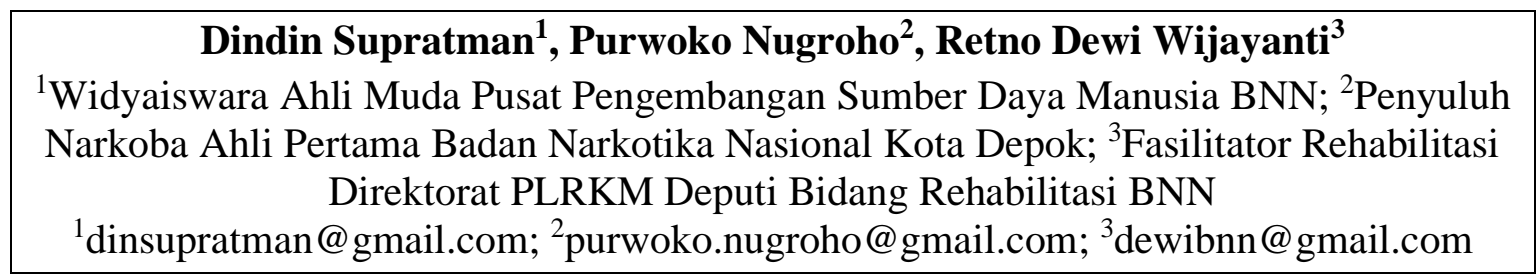

Diterima: Januari 2020; Direvisi: Maret 2020; Disetujui: April 2020

Abstract. The rise of narcotics abuse in Indonesia, reaching a prevalence of $1.77 \%$ in 2017, certainly requires serious treatment. One of the efforts made is the curative approach, which since the Joint Regulation was issued in 2015, the Integrated Assessment Team (TAT) program has been carried out. The purpose of this study was to analyze the effectiveness of the TAT program at BNNK in South Jakarta, as the BNNK 2018. The research method is quantitative descriptive, where sampling uses a purposive sampling method, involving 34 respondents. Data was collected using a questionnaire which was then analyzed using the Factor Analysis test with the application of IBM SPSS 23 and Lisrel 8.8 and the Linear Regression test with IBM SPSS 23. The results showed the TAT program at BNNK South Jakarta was positively influenced by 3 components with an effectiveness level reaching $75.7 \%$. Another factor expected to influence the effectiveness of the TAT program is coordination, according to the results of interviews with the South Jakarta BNNK TAT team.

\section{Keyword: South Jakarta BNNK, Effectiveness, TAT}

\begin{abstract}
Abstrak. Maraknya penyalahgunaan Narkotika di Indonesia, hingga mencapai angka prevalensi $1,77 \%$ pada tahun 2017 , tentu membutuhkan penanganan yang serius. Salah satu upaya yang dilakukan yakni pendekatan kuratif, dimana sejak Peraturan Bersama dikeluarkan pada tahun 2015, telah dilakukan program Tim Asesmen Terpadu (TAT). Tujuan penelitian ini adalah untuk menganalisa efektivitas program TAT di BNNK Jakarta Selatan. Metode penelitian bersifat deskriptif kuantitatif, dimana pengambilan sampel menggunakan metode purposive sampling, melibatkan 34 responden. Pengumpulan data dilakukan menggunakan kuesioner yang kemudian dianalisis menggunakan uji Analisis Faktor dengan aplikasi IBM SPSS 23 dan Lisrel 8.8 serta uji Regresi Linear dengan IBM SPSS 23. Hasil penelitian menunjukkan program TAT di BNNK Jakarta Selatan dipengaruhi positif oleh 3 komponen dengan tingkat efektivitas mencapai 75,7\%. Faktor lain yang diperkirakan memengaruhi efektivitas pelaksanaan program TAT adalah koordinasi, sesuai dengan hasil wawancara kepada tim TAT BNNK Jakarta Selatan.
\end{abstract}

\section{Kata kunci: BNNK Jakarta Selatan, Efektivitas, TAT}

\section{PENDAHULUAN}

Permasalahan penyalahgunaan narkotika merupakan permasalahan serius dan telah banyak menyebabkan kerugian bagi individu, keluarga, bahkan sebuah negara, baik materi maupun non materi. Data penelitian yang dilakukan oleh BNN pada tahun 2017, tercatat angka prevalensi penyalahgunaan Narkotika di Indonesia mencapai $1,77 \%$ atau dengan kata lain sebanyak 3.376.115 penduduk Indonesia telah menyalahgunakan Narkotika. Dari 
penelitian tersebut juga diperoleh data bahwa dari 34 provinsi di Indonesia, DKI Jakarta merupakan provinsi dengan angka prevalensi terbesar, yakni $3,34 \%$ atau sekitar 260.656 penduduk DKI Jakarta telah menyalahgunakan Narkotika (Badan Narkotika Nasional 2017).

Salah satu fungsi dari Badan Narkotika Nasional adalah melaksanakan Tim Asesmen Terpadu (TAT) untuk rehabilitasi terhadap pemakai dan pecandu narkoba. Kegiatan TAT ini memiliki tugas yaitu asesmen dan analisis medis, psikososial, serta merekomendasi rencana terapi dan rehabilitasi seseorang yang ditangkap dan/atau tertangkap tangan serta melakukan analisis terhadap seseorang yang ditangkap dan/atau tertangkap tangan dalam kaitan peredaran gelap Narkotika dan penyalahgunaan Narkotika. Adapun pelaksanaan TAT di Indonesia sesuai dengan peraturan sudah diatur.

Dalam usaha untuk menanggulangi masalah penyalahgunaan dan peredaran gelap narkotika, pemerintah telah memberlakukan Undang-Undang No. 35 Tahun 2009 tentang Narkotika. Pada dasarnya sanksi yang diatur dalam UndangUndang Narkotika menganut double track system yaitu berupa sanksi pidana dan sanksi tindakan. Dalam perkembangannya penyalahgunaan dan pecandu narkotika tidak lagi bermuara pada sanksi pidana penjara, melainkan rehabilitasi melalui proses asesmen oleh Tim Asesmen Terpadu.

Pelaksanaan asesmen terpadu di Indonesia masih mengalami berbagai kendala yaitu: a) adanya perbedaan pandangan diantara aparat penegak hukum dalam penanganan kasus narkotika; b) ketentuan hukum yang mengatur asesmen terpadu kurang mempunyai kekuatan hukum; c) kurangnya anggaran/sumber dana dalam pelaksanaan assesmen terpadu. Oleh karena itu harus ada tindakan dan perhatian dari pemerintah (BNN) mulai dari pemahaman aparat penegak hukum dalam pemberantasan tindak pidana narkotika, penggunaan instrumen hukum yang tepat, dan anggaran yang cukup, harus menjadi perhatian serius pemerintah dikarenakan penyalahgunaan narkotika selalu meningkat setiap harinya yang dapat mengancam warga masyarakat dari berbagai kalangan dan usia.

Pada tahun sebelumnya (2016), penelitian yang dilakukan oleh BNN menunjukkan bahwa $40 \%$ penghuni lapas di Indonesia terkait dalam kasus kejahatan Narkotika. Data dari laman Direktorat Jenderal Pemasyarakatan (Ditjenpas) Kementerian Hukum dan HAM pada bulan Oktober dari tahun 2016 sampai dengan 2018 menunjukkan bahwa jumlah tahanan dan napi yang ada di dalam lapas dan rutan di Indonesia mencapai berturut-turut 201.553 orang, 228.328 orang dan 251147 orang, sementara daya tampung dari lapas dan rutan pada bulan dan tahun yang sama berturut-turut 122.493 orang, 124.529 orang dan 124.989 orang. Dari jumlah tersebut, didapati masih ada pecandu Narkotika yang dikenai hukuman penjara, yakni berturutturut 28.384 orang, 37.742 orang dan 12.292 orang. Jika tidak ada penanganan yang serius, maka diperkirakan akan terjadi over capacity dan kenaikan angka prevalensi penyalahgunaan Narkotika.

Kondisi tersebut sangat bertolak belakang dengan Undang-Undang Nomor 35 tahun 2009, dimana pada pasal 103 ditegaskan bahwa hakim dapat memutus atau menetapkan pecandu narkotika untuk menjalani pengobatan dan/atau perawatan. Hal itu juga diperkuat dengan adanya Surat Edaran Mahkamah Agung Nomor 04 tahun 2010 tentang Penempatan Penyalahgunaan, 
Korban Penyalahgunaan dan Pecandu Narkotika ke dalam Lembaga Rehabilitasi Medis dan Rehabilitasi Sosial. Melalui kedua peraturan tersebut sangat jelas bahwa seorang pecandu Narkotika tetap mendapatkan penghukuman, namun bentuk penghukumannya berupa Rehabilitasi. Bentuk pengalihan tersebut dikenal dengan istilah dekriminalisasi pecandu Narkotika.

Melihat adanya perbedaan pendapat tersebut, maka pada tahun 2015 dilakukan sebuah kesepakatan bersama antara tujuh kementerian/ lembaga yakni Kementerian Sosial RI, Kementerian Kesehatan RI, Mahkamah Agung RI, Kementerian Hukum dan Hak Asasi Manusia RI, Jaksa Agung RI, Kepolisian Negara RI dan BNN RI. Hasil kesepakatan tersebut melahirkan Peraturan Bersama tentang Penenganan Pecandu Narkotika dan Korban Penyalahgunaan Narkotika ke dalam lembaga Rehabilitasi. Tujuan dari dikeluarkannya peraturan bersama ini adalah untuk mewujudkan koordinasi dan kerjasama secara optimal dalam penyelesaian permasalahan Narkotika dalam rangka menurunkan jumlah Pecandu Narkotika dan Korban Penyalahgunaan Narkotika melalui program pengobatan, perawatan, dan pemulihan dalam penanganan Pecandu Narkotika dan Korban Penyalahgunaan Narkotika sebagai tersangka, terdakwa atau Narapidana, dengan tetap melaksanakan pemberantasan peredaran gelap Narkotika.

Melalui Peraturan Bersama tersebut lahirlah sebuah program Tim Asesmen Terpadu yang berkedudukan di tingkat pusat, tingkat propinsi, tingkat kabupaten/kota terdiri dari tim dokter dan tim hukum yang bertugas melaksanakan analisis peran tersangka yang ditangkap atas permintaan penyidik yang berkaitan dengan peredaran gelap narkotika terutama bagi pecandu. Tim tersebut kemudian melaksanakan analisis hukum, analisis medis dan analisis psikososial serta membuat rencana rehabilitasi yang memuat berapa lama rehabilitasi diperlukan. Hasil asesmen tersebut sebagai kelengkapan berkas perkara berfungsi sebagai keterangan seperti visum et repertum.

Program TAT sendiri sudah mulai dilaksanakan dari tahun 2015 hingga saat ini, baik di tingkat BNN pusat maupun di tingkat BNN Provinsi dan Kabupaten/Kota. Namun demikian, pelaksanaan kebijakan TAT tersebut masih belum diketahui apakah sudah berjalan efektif atau belum. Dalam beberapa kajian justru diperoleh informasi bahwa pelaksanaan TAT masih jauh dari harapan, bahkan kondisi yang terburuk justru TAT sering dijadikan lahan basah oleh oknum petugas untuk mencari keuntungan dengan menjadikan hukuman penjara dan rehabilitasi sebagai sebuah ajang transaksi yang bisa diperjualbelikan.

BNN Kota Jakarta Selatan, merupakan salah satu BNN Kota yang ada di wilayah DKI Jakarta, selain BNN Kota Jakarta Timur dan Jakarta Utara. Sebagai perpanjangan tangan BNN di wilayah Jakarta Selatan, BNN Kota Jakarta Selatan juga turut melaksanakan program TAT bagi para pecandu Narkotika yang terjerat pidana. Hasil capaian pelaksanaan program TAT di BNN Kota Jakarta Selatan, selalu mencapai over prestasi, yakni melebihi target yang telah ditetapkan. Adapun pencapaian program TAT di BNN Kota Jakarta Selatan dari tahun 2015 hingga 2018 berturut turut 81 (target: 60); 172 (target: 100); 212 (target: 155) dan 226 (target: 125) (data Seksi Rehabilitasi BNN Kota Jakarta Selatan 2015-2018). Pencapaian tersebut tentu merupakan prestasi yang dapat ditiru oleh BNN Kabupaten/Kota lainnya. Namun demikian, 
perlu juga dilihat tingkat efektivitas pelaksanaan program TAT tersebut. Hal ini penting karena di era Reformasi Birokrasi saat ini, pelaksanaan sebuah program pemerintah dituntut untuk efektif, efisien dan bermutu. Apabila suatu program tidak memenuhi unsur efektif, efisien dan bermutu, maka walaupun program tersebut berjalan dengan baik tetap akan dinilai tidak baik dan menjadi bahan evaluasi bagi Kementerian/Lembaga yang mengempu program tersebut.

Oleh karena itu, pada penelitian ini penulis ingin menganalisa efektivitas pelaksanaan program TAT pada BNN Kota Jakarta Selatan. Melalui penelitian ini, diharapkan akan memberikan gambaran kepada BNN khususnya kepada Deputi Rehabilitasi mengenai pelaksanaan kebijakan TAT di BNN Kota Jakarta Selatan serta dapat memberikan sumbangan saran bagaimana program TAT tersebut dapat berjalan efektif. Lebih luas, melalui penelitian ini diharapkan mampu menurunkan angka permintaan (demand) pada kelompok pecandu Narkotika sehingga akan berdampak pada menurunnya angka prevalensi penyalahgunaan Narkotika di Indonesia.

\section{METODE PENELITIAN}

Penelitian ini merupakan penelitian kuantitatif, dimana akan mengukur efektivitas dari kebijakan TAT di BNN Kota Jakarta Selatan. Metode pengambilan sampel yang digunakan dalam penelitian ini adalah purposive sampling, dimana sampel yang akan digunakan dipilih oleh peneliti berasal dari tim TAT di BNN Kota Jakarta Selatan (tim medis dan tim hukum) serta pecandu Narkotika yang telah menjalani program TAT. Jumlah total responden sebanyak 34 orang, terdiri dari: BNNP DKI Jakarta (2 orang); BNNK Jakarta Selatan (4 orang); Polres Jakarta Selatan (12 orang); Polsek Jagakarsa (2 orang); Polsek Mampang (2 orang); Polsek Pasar Minggu (2 orang); Polsek Cilandak (1 orang); Polsek Tebet (1 orang); Kejaksaan Jakarta Selatan (1 orang) dan Pecandu Narkotika yang masih menunggu hasil putusan sidang setelah menjalani program TAT di Polres Jakarta Selatan (7 orang). Karakteristik dari responden adalah pria sebanyak 27 orang $(79,4 \%)$ dan wanita sebanyak 7 orang (20,6\%); latar belakang pendidikan mulai dari SMP hingga S3 (Doktor) dan rentang usia dari 23 tahun hingga 57 tahun.

Teknik pengumpulan data menggunakan kuesioner yang dibagikan langsung kepada responden dan ada pula yang dibagikan menggunakan google form (link: goo.gl/forms/xW1cr9nhyzfxxMt23). Dalam kuesioner penelitian, terdapat 19 item pertanyaan yang mewakili 5 (lima) indikator efektivitas, yakni Sosialisasi, Pemahaman, Tujuan, Tepat Sasaran dan Perubahan Nyata, serta ada 1 item pertanyaan yang mengukur penilaian responden terhadap pelaksanaan program TAT (pertanyaan nomor 6).

\begin{tabular}{|l|l|}
\hline \multicolumn{1}{|c|}{ Indikator } & Nomor Pertanyaan \\
\hline Sosialisasi & $1,2,3$ \\
\hline Pemahaman & $4,5,7,9$ \\
\hline Tujuan & $8,10,13,14$ \\
\hline Tepat Sasaran & $12,16,17,18$ \\
\hline Perubahan Nyata & 19,20 \\
\hline
\end{tabular}

Hasil pengisian kuesioner terlebih dahulu dilakukan uji validitas dan reliabilitas menggunakan aplikasi IBM SPSS 23 untuk mengetahui apakah kuesioner tersebut valid dan reliabel. Uji selanjutnya adalah analisis faktor menggunakan aplikasi IBM SPSS 23 dan Lisrel 8.8 guna mengetahui pengelompokan dari 19 pertanyaan yang ada dalam 
kuesioner penelitian. Dilanjutkan dengan Uji regresi linear yang dilakukan untuk melihat:

- Persamaan regresi dari Efektivitas Pelaksanaan Program TAT.

- Mengetahui indikator mana yang paling memengaruhi efektivitas program TAT.

- Mengetahui persentase indikator yang digunakan dalam memengaruhi program TAT.

- Apakah masih ada indikator lain, disamping 5 (lima) indikator yang ada, yang mampu menjelaskan terkait efektivitas.

Sebagai variabel dependent adalah penilaian responden akan pelaksanaan TAT, yang diwakili oleh pertanyaan nomor 6, sementara sebagai variabel independent adalah 3 kelompok faktor yang dihasilkan pada perhitungan SPSS. Sebelumnya dilakukan metode succesive interval guna mengubah data penilaian responden yang semula berbentuk ordinal menjadi interval, agar dapat dilakukan pengujian regresi linear.

Disamping menggunakan kuesioner, dilakukan pula wawancara terhadap perwakilan tim medis dan tim hukum dalam TAT serta perwakilan pecandu Narkotika yang masih berada dalam tahanan Polres Jakarta Selatan. Data wawancara ini sebagai pendukung data yang diperoleh dari pengisian kuesioner.

\section{HASIL DAN PEMBAHASAN}

\section{a. Uji Validitas dan Reliabilitas}

Uji yang pertama kali dilakukan adalah validitas dan reliabilitas. Tujuan dari pengujian ini adalah untuk membuktikan pertanyaan-pertanyaan yang disusun merupakan pertanyaan yang valid dan reliabel. Untuk pengujian ini, menggunakan aplikasi IBM SPSS 23. Hasil pengujian menunjukkan bahwa data yang didapat reliabel (Cronbach's Alpha 0,936) dan valid (Corrected Item-Total Correlation > 0,3)

\section{b. Uji Analisis Faktor}

Uji analisis faktor digunakan untuk melihat dari pertanyaan yang ada dalam kuesioner, dapat dikelompokkan menjadi berapa komponen atau variabel. Dalam menguji analisis faktor, digunakan software SPSS IBM 23 dan Lisrel 8.8. Hasil uji tersebut menunjukkan nilai KMO Bartlett sebesar 0,784 dan nilai signifikansi 0,00 (lebih kecil dari 0,05) sehingga dapat dikatakan secara keseluruhan model kuesioner baik. Dari Tabel Anti Image Correlation, didapat nilai dari tiap faktor lebih besar dari 0,5, artinya tiap faktor dapat digunakan. Kemudian dari hasil nilai Eigenvalue didapat, 16 pertanyaan dalam kuesioner dapat dikelompokkan menjadi 3 kelompok. Adapun pengelompokkannya sebagai berikut:

- Komponen 1 terdiri dari: pertanyaan $9,8,10,12,18,11,15$

- Komponen 2 terdiri dari: pertanyaan $7,13,14,19,20$

- Komponen 3 terdiri dari: pertanyaan $2,3,4,5$

Hasil analisis peneliti berdasarkan karakteristik pertanyaan, ketiga komponen itu menjelaskan tentang:

- Komponen 1 merupakan gabungan antara indikator Tujuan dan Tepat Sasaran

- Komponen 2 merupakan indikator Perubahan Nyata

- Komponen 3 merupakan gabungan antara indikator Sosialisasi dan Pemahaman

Hasil pengujian analisis faktor melalui SPSS hanya mengelompokkan 19 pertanyaan yang ada ke dalam 3 kelompok. 
Hasil yang didapat tidak sesuai dengan apa yang diharapkan penulis, yaitu terdapat 5 kelompok (sesuai indikator yang digunakan). Hal tersebut kemungkinan disebabkan bentuk pertanyaan yang penulis susun kurang mengarah kepada indikator yang dimaksud. Namun demikian, penulis mencoba menggunakan aplikasi Lisrel 8.8, guna melihat apakah benar indikator yang didapat hanya 3, atau ada faktor lain yang menyebabkan hasil analisis faktor menggunakan SPSS hanya terdapat 3 komponen/indikator saja.

Pengujian menggunakan Lisrel 8.8 didapat hasil sebagai berikut:

- Pola/hubungan yang penulis susun:

VAR00001-VAR00003 = Sosialisasi

VAR00004-VAR00007 = Pemahaman

VAR00008-VAR00011 $=$ Tujuan

VAR00012-VAR00015 $=\quad$ Tepat Sasaran

VAR00016-VAR00019 = Perubahan Nyata

Sosialisasi Pemahaman Tujuan Tepat Sasaran Perubahan Nyata $=$ Efektivitas

- Berdasarkan hasil Loading Factor dan nilai Uji $t$ yang didapat, dari 19 pertanyaan, hanya 2 pertanyaan yang tidak bisa menjelaskan pola hubungan yang dibuat, yakni pertanyaan 17 (VAR00014) tidak bisa menjelaskan indikator Tepat Sasaran dan pertanyaan 15 (VAR00019) tidak bisa menjelaskan indikator Perubahan.

Interpretasi data menggunakan lisrel

8.8:

- Bahwa hasil pengujian SPSS menyatakan 19 pertanyaan yang diajukan dapat dikelompokkan menjadi 3 komponen.
Setelah dilakukan pengujian menggunakan Lisrel, didapatkan bahwa 5 komponen (indikator) berupa sosialisasi, pemahaman, tujuan, tepat sasaran dan perubahan nyata dapat di jelaskan oleh 17 varian, yaitu :

o Pernah tidaknya memperoleh sosialisasi, kesesuaian materi yang diperoleh dari sosialisasi dengan kebutuhan satker dan sosialisasi yang diperoleh membantu pelaksanaan program TAT, kesemuanya dapat menjelaskan untuk indikator sosialisasi.

- Pemahaman tujuan program TAT, syarat TAT, tim medis serta tim hukum tentang proses TAT dapat digunakan untuk menjelaskan indikator pemahaman.

- Pelaksanaan asesmen medis oleh tim medis, pelaksanaan asesmen hukum oleh tim hukum, penuntutan Jaksa Penuntut Umum dan pemberian vonis Rehabilitasi oleh Hakim dapat menjelaskan untuk indikator tujuan.

- Batasan waktu pecandu Narkotika yang mengikuti program TAT, pecandu Narkotika telah mendapat hukuman Rehabilitasi, Rehabilitasi pecandu Narkotika dilakukan di Lembaga Rehabilitasi, baik medis maupun sosial dan program TAT hanya diperuntukkan bagi pecandu Narkotika dapat menjelaskan indikator tepat sasaran.

- Pecandu Narkotika yang telah direhabilitasi dapat pulih kembali dan program TAT mampu mengurangi jumlah pecandu Narkotika dalam Lapas dapat menjelaskan indikator perubahan nyata. 


\section{c. Uji Regresi Linear}

Disamping analisis faktor, penulis juga ingin melihat, seberapa besar indikator yang digunakan memengaruhi efektifitas program TAT. Untuk itu, penulis mencoba melakukan uji regresi linear. Hasil pengujian, didapat:

- Persamaan regresi:

$\mathrm{Y}$ (efektifitas) $=2,677+0,179$

(Komponen 1) + 0,715 (Komponen 2) $+0,417$ (Komponen 3)

- Uji F menunjukkan nilai signifikansi sebesar 0,000 (lebih kecil dari 0,05) sehingga model persamaan yang didapat, layak digunakan

- Uji t menunjukkan nilai signifikansi ketiga komponen lebih kecil dari 0,05 , yang berarti ketiga komponen memang memengaruhi efektivitas.

- Uji R menunjukkan nilai adjusted $\mathrm{R}^{2}$ sebesar 0,757 , artinya persamaan yang didapat hanya menjelaskan 75,7\% efektivitas. Masih ada indikator lain sebesar $24,3 \%$ yang memengaruhi efektivitas.

- Berdasarkan persamaan regresi yang didapat, terlihat bahwa:

i. kenaikan 1 satuan Komponen 1, akan meningkatkan efektivitas sebesar 0,179

ii. kenaikan 1 satuan Komponen 2, akan meningkatkan efektivitas sebesar 0,715

iii.kenaikan 1 satuan Komponen 3, akan meningkatkan efektivitas sebesar 0,417

\section{d. Deskriptif}

Disamping pengujian statistik, dilakukan juga pengujian secara deskriptif, yakni menilai persentase dari tiap indikator. Hasil yang didapat sebagai berikut:
1. Indikator Sosialisasi

Indikator sosialisasi meliputi 3 pertanyaan penelitian, yakni pernah tidaknya mendapat sosialisasi, kesesuaian materi sosialisasi dengan kebutuhan satker, dan apakah sosialisasi membantu pelaksanaan TAT.

a. Untuk poin pernah tidaknya sosialisasi, responden yang berasal dari BNNP DKI, BNNK Jakarta Selatan, POLRES dan POLSEK di Jakarta Selatan serta Kejaksaan Negeri Jakarta Selatan, mayoritas telah mendapat sosialisasi mengenai program TAT. Namun, yang perlu menjadi perhatian bagi BNNK agar turut mensosialisasikan program TAT kepada masyarakat sehingga masyarakat pun mengetahui hak mereka ketika mereka tertangkap tangan sebagai pecandu Narkotika.

b. Untuk poin kesesuaian materi dengan kebutuhan satker, secara keseluruhan, materi yang disampaikan dinilai sudah cukup sesuai dengan kebutuhan satker masing-masing responden.

c. Untuk poin sosialisasi membantu pelaksanaan program TAT di satker, secara keseluruhan, sosialisasi yang dilakukan telah membantu pelaksanaan program TAT di satker masing-masing responden.

2. Indikator Pemahaman

Indikator pemahaman meliputi 4 pertanyaan penelitian, yakni pemahaman tentang tujuan program TAT, pemahaman tentang syarat program, pemahaman tim medis akan 
asesmen medis, dan pemahaman tim hukum akan asesmen hukum.

a. Untuk poin pemahaman tentang tujuan program TAT secara keseluruhan, responden yang telah mendapat sosialisasi program TAT, telah memahami tujuan dari program TAT, yakni menjangkau para pecandu Narkotika yang tertangkap aparat penegak hukum agar mendapat layanan Rehabilitasi. Harapannya, pecandu Narkotika tersebut dapat pulih sehingga dapat menurunkan angka prevalensi penyalahgunaan Narkotika

b. Untuk poin pemahaman tentang syarat program TAT secara keseluruhan, responden yang telah mendapat sosialisasi program TAT, telah memahami syarat-syarat mengikuti program TAT. Ada 13 responden yang belum mengetahui syarat mengikuti program TAT, hal tersebut bisa jadi karena memang ada beberapa responden yang belum mendapat sosialisasi atau pemberian sosialisasi yang dilakukan belum menyeluruh. Tentu ini menjadi koreksi bagi BNNK agar memerhatikan pemahaman peserta sosialisasi sehingga program TAT dapat berjalan sesuai aturan.

c. Untuk poin pemahaman tim medis akan proses asesmen medis yang baik. Poin ini sangat penting karena dalam TAT, tim medis memegang peran penting dalam menentukan seorang pecandu Narkotika apakah memang sebagai pecandu Narkotika kemudian layanan rehabilitasi seperti apa yang dibutuhkan oleh pecandu tersebut.
Secara keseluruhan, tim medis dalam TAT di BNNK Jakarta Selatan dinilai telah memahami proses asesmen dengan baik.

d. Untuk poin pemahaman tim hukum akan proses asesmen hukum yang baik. Sama halnya dengan tim medis, tim hukum pun memegang peran penting dalam TAT. Tim hukum harus memahami proses asesmen hukum dengan baik agar dapat menentukan kriteria penyalahguna Narkotika yang tertangkap memang benar sebagai pecandu Narkotika murni atau terlibat dalam jaringan sindikat Narkotika.

3. Indikator Tujuan

Indikator tujuan meliputi 4 pertanyaan penelitian, yakni pelaksanaan asesmen medis oleh tim medis, pelaksanaan asesmen hukum oleh tim hukum, penuntutan Jaksa Penuntut Umum, dan pemberian vonis Rehabilitasi oleh Hakim.

a. Untuk poin pelaksanaan asesmen medis oleh tim medis, menunjukan angka yang signifikan yakni $76,47 \%$ menjawab setuju. Dengan kata lain pelaksanaan assessmen oleh tim medis di BNNK Jakarta Selatan sudah berjalan dengan baik.

b. Untuk poin pelaksanaan asesmen hukum oleh tim hukum, menunjukan angka yang signifikan yakni $79,41 \%$ menjawab setuju. Pelaksanaan assessmen oleh tim hukum di BNNK Jakarta Selatan sudah berjalan dengan baik

c. Untuk poin penuntutan Jaksa Penuntut Umum, hanya 50\% yang menjawab setuju, sisanya $11,76 \%$ ) 
menjawab ragu-ragu $38,23 \%$ menjawab tidak setuju.

d. Untuk poin pemberian vonis Rehabilitasi oleh Hakim, sebanyak sebanyak 35,29\% menjawab setuju, $17,65 \%)$ menjawab ragu-ragu dan $47,06 \%$ menjawab tidak setuju.

4. Indikator Tepat Sasaran

Indikator Tepat Sasaran meliputi 4 pertanyaan penelitian, yakni batasan pecandu Narkotika yang mengikuti program TAT, pecandu Narkotika telah mendapat hukuman Rehabilitasi, Rehabilitasi pecandu Narkotika dilakukan di Lembaga Rehabilitasi, baik medis maupun sosial, dan program TAT hanya diperuntukkan bagi pecandu Narkotika.

a. Untuk poin batasan pecandu Narkotika yang mengikuti program TAT, $64,71 \%$ menjawab setuju, $8,82 \%$ menjawab ragu-ragu, dan $26,47 \%$ menjawab tidak setuju.

b. Untuk poin pecandu Narkotika telah mendapat hukuman

Rehabilitasi, sebanyak 55,88\% menjawab setuju $(2,94 \%$ menjawab ragu-ragu, dan $41,18 \%$ menjawab tidak setuju.

c. Untuk poin Rehabilitasi pecandu Narkotika dilakukan di Lembaga Rehabilitasi, baik medis maupun sosial, sebanyak 55,88\% menjawab setuju, 2,94\% menjawab raguragu, dan $41,18 \%$ menjawab tidak setuju.

d. Untuk poin program TAT hanya diperuntukkan bagi pecandu Narkotika, sebanyak 27 orang $(79,41 \%)$ menjawab setuju (dengan komposisi: 5 orang memberi nilai 5,4 orang memberi nilai 6 dan 18 orang memberi nilai 7 ); 1 orang
$(2,94 \%)$ menjawab ragu-ragu (nilai: 4) dan 6 orang $(17,65 \%)$ menjawab tidak setuju (dengan komposisi: 5 orang memberi nilai 2 dan 1 orang memberi nilai 3 ).

5. Indikator Perubahan Nyata

Indikator Perubahan Nyata meliputi 2 pertanyaan penelitian, yakni pecandu Narkotika dapat pulih kembali, dan program TAT mampu mengurangi jumlah pecandu Narkotika dalam Lapas.

a. Untuk poin pecandu Narkotika dapat pulih kembali, sebanyak $38,23 \%$ menjawab setuju, $32,35 \%$ ) menjawab ragu-ragu, dan $29,41 \%$.

b. Untuk poin program TAT mampu mengurangi jumlah pecandu Narkotika dalam Lapas, sebanyak $55,88 \%$ ) menjawab setuju, $11,77 \%$ menjawab ragu-ragu, dan 32,35\% menjawab tidak setuju.

6. Indikator Koordinasi

Disamping kelima indikator tersebut, penulis juga mencoba mengajukan indikator lain, yakni Koordinasi. Adapun indikator tersebut meliputi 2 pertanyaan penelitian, yakni koordinasi tim medis dan tim hukum dalam program TAT dan koordinasi antar satker/instansi dalam program TAT.

a. Untuk poin koordinasi tim medis dan tim hukum dalam program TAT, sebanyak 79,41\% menjawab setuju, 5,88\% menjawab ragu-ragu dan 14,71 menjawab tidak setuju.

b. Untuk poin koordinasi antar satker/instansi dalam program TAT, sebanyak 73,53\% menjawab setuju, $8,82 \%$ menjawab ragu-ragu, dan $17,65 \%$ menjawab tidak setuju. 
Berdasarkan pengujian tersebut diatas secara deskriptif, dapat disimpulkan bahwa program TAT yang dilaksanakan di BNNK Jakarta Selatan dapat dikatakan efektif berdasarkan kelima indikator yang dinilai yaitu sosialisasi, pemahaman, tujuan, tepat sasaran dan perubahan nyata, yang kesemua indikatornya dapat dijelaskan melalui 19 varian pertanyaan yang diujikan, hal ini sesuai dengan yang dijelaskan dalam teori Budiani (2009) bahwa efektifitas adalah adanya kesesuaian antara output dengan tujuan yang ditetapkan. Suatu program dapat dikatakan efektifit jika berjalan sesuai dengan yang dikehendakinya. Efektifitas harus dinilai atas dasar tujuan yang bisa dilaksanakan, bukan atas dasar konsep tujuan yang maksimum (Richard Steer). Hal ini menjelaskan bahwa suatu program dapat dinilai efektif bukan hanya dari hasil akhir yang diperolehnya nanum dari kesesuaian alur atau proses yang terjadi didalamnya.

Pemahaman Program TAT yang dimiliki oleh tim pelaksana TAT dan masyarakat yang memungkinkan bisa menjadi pecandu narkotika, akan mendukung terlaksananya program TAT secara efektif, karena dengan adanya pemahaman dalam diri sendiri maka akan dapat meningkatkan hasil yang diinginkan, hal ini sesuai dengan yang dikemukakan oleh Linn Rebecca-Walton and Maschi Tina (2015) bahwa wawasan dan motivasi merupakan kunci keberhasilan dalam layanan rehabilitasi.

Pencapaian tujuan yang telah ditentukan dalam pelaksanaan program TAT dapat memengaruhi penilaian efektivitas, hal ini sesuai dengan Bungkaes (2013), yang menjelaskan bahwa efektifitas adalah hubungan antara output dan tujuan. Dalam hal ini diukur seberapa besar output yang dikeluarkan dalam mencapai tujuan yang telah dietapkan.
Tepat Sasaran yang dimaksudkan adalah peruntukan program TAT untuk pecandu narkotika yang tidak terlibat dengan jaringan peredaran gelap, hal ini juga didukung oleh jumlah barang bukti yang tertangkap tangan berada di bawah jumlah yang tertera dalam SEMA (Surat Edaran Mahkamah Agung). Rehabilitasi yang diperuntukan bagi pecandu narkotika dapat dinilai efektif karena pecandu narkotika merupakan merupakan seseorang yang sakit dengan gangguan yang berkaitan dengan efek atau reaksi narkotika dalam otaknya.

Perubahan nyata yang dinilai adalah kondisi ketika pecandu narkotika selesai memperoleh layanan rehabilitasi. Walaupun tidak ada yang menjamin berapa lama pecandu narkotika akan dapat pulih tanpa menggunakan narkotika (abstinatia), akan tetapi tujuan dari pemberian layanan rehabilitasi adalah memulihkan pecandu sehingga dapat produktif kembali dalam masyarakat. Tujuan pulih dan produktif kembali dapat dirasakan oleh pecandu melalui persepsi mengenai posisi mereka dalam hidup sesuai konteks budaya dan sistem nilai dimana mereka hidup dan hubungannya dengan tujuan, harapan, standar yang ditetapkan dan perhatian seseorang yang terdiri dari dimensi kualitas hidup yaitu dimensi kesehatan fisik, dimensi kesejahteraan psikologis, dimensi hubungan sosial dan dimensi hubungan lingkungan (Lopez dan Snyder, 2004). Hal ini dapat menjadi salah satu indikator dalam menilai efektivitas program TAT.

Pada nilai $\mathrm{R}^{2}$ diperoleh hasil 0,757 , yang menunjukkan masih ada indikator lain yang memengaruhi efektivitas. Oleh karena itu, penulis mencoba memasukkan indikator "Koordinasi" sebagai salah satu indikator yang memengaruhi efektivitas pelaksanaan program TAT. Penambahan indikator koordinasi dapat menunjang penilaian 
efektivitas suatu program, hal ini juga di perkuat dengan adanya masukan dan saran dari responden yaitu dari petugas medis di BNNP DKI Jakarta yang merupakan tim medis TAT di Jakarta Selatan yang mengatakan untuk "memperkuat sinergitas antar instansi yang terkait". Hal ini didukung oleh Petugas administrasi dari BNNK Jaksel yang memberikan saran agar "lebih bersinergi lagi dengan instansi terkait lain terkait TAT yang sudah berjalan ". Masukan dari penyidik Polres Jakarta Selatan adalah "tahanan narkotika jangan dicampur agar dikonsultasikan jaksa dan hakim". Kenyataan yang saat ini berjalan di lapangan adalah tidak adanya laporan terkait hasil putusan dari Hakim terhadap tersangka pecandu narkotika apakah menjalani layanan rehabilitasi atau tidak kepada pihak penyidik dan tim medis BNNK Jakarta selatan, sehingga pihak BNNK dan penyidik tidak mengetahui seberapa banyak jumlah tersangka pecandu narkotika yang berhasil memperoleh layanan rehabilitasi. Oleh karena itu sangat dibutuhkan suatu koordinasi antara tim medis di BNNK dengan penyidik dan kejaksaan yang keduanya merupakan tim Hukum, terkait laporan akhir dari proses TAT yang berlangsung.

Hasil wawancara yang didapat pun juga menunjukkan hasil yang serupa, dimana kunci penting dalam program TAT berada pada penyidik, jaksa dan hakim. Jika dari sejak awal penyidik telah mencantumkan pasal 127 tunggal maka baik Jaksa maupun Hakim akan memutus vonis Rehabilitasi terhadap pecandu Narkotika. Namun yang terjadi di lapangan justru penyidik tidak berani mencantumkan pasal 127 tunggal, biasanya mereka menggabungkan dengan pasal pidana (pasal 111 dan seterusnya). Hal ini karena timbul kekhawatiran dari penyidik, apabila tersangka pecandu hanya didakwa pasal 127, maka siapa yang akan menjamin keamanan tersangka tersebut (dikhawatirkan melarikan diri). Alasan lain yang diajukan oleh penyidik adalah adanya kecurigaan dari atasan maupun rekan penyidik lainnya apabila ditetapkan pasal 127 tunggal maka penyidik tersebut dicurigai melakukan pemerasan terhadap tersangka pecandu Narkotika. Fenomena ini perlu mendapat perhatian, dimana artinya masih ada celah dalam teknis pelaksanaan TAT dan ini perlu untuk diperbaiki.

Di satu sisi, penyidik pun juga dituntut pro aktif terhadap kasus Narkotika yang ditanganinya. Hal ini karena penulis menemukan bahwa penyidik kurang pro aktif dalam menindaklanjuti kasus Narkotika yang ditanganinya. Ketika berkas perkara sudah masuk ke Kejaksaan maka seolah-olah penyidik tidak lagi memiliki kepentingan. Hal ini terlihat dari ketidaktahuan penyidik berapa banyak tersangka pecandu Narkotika yang sudah diajukan ke Jaksa dan sudah dijatuhi vonis, namun penyidik tidak mengetahui isi vonis Hakim. Memang secara aturan, ketika berkas perkara sudah masuk ke Kejaksaan, tidak ada lagi kewajiban penyidik terhadap tersangka tersebut. Namun demikian, bukan berarti seorang penyidik sama sekali berlepas tangan. Karena hal tersebut akan menyulitkan dalam menentukan keberhasilan program TAT yang telah dijalankan.

Keberadaan Jaksa juga tidak kalah pentingnya, dimana ketika seorang Jaksa memiliki pemahaman yang sama terkait TAT, konsep Rehabilitasi dan Dekriminalisasi Penyalahguna Narkotika, maka ketika didapati penyidik memberikan pasal 127 juncto pasal pidana, maka Jaksa berhak mengembalikan berkas penyidikan (P18 atau P19) dan meminta penyidik untuk hanya mencantumkan pasal 127 tunggal. 
Namun demikian, sama halnya dengan penyidik, apabila Jaksa menerapkan pasal 127 tunggal akan dicurigai bermain mata dengan tersangka atau keluarga tersangka.

Sama halnya dengan Hakim, bahwa sesungguhnya pada pasal 103 UU 35 tahun 2009 telah dicantumkan bahwa Hakim memiliki kewenangan untuk memutus vonis Rehabilitasi bagi pecandu Narkotika. Namun yang terjadi, sampai dengan saat ini masih banyak pecandu Narkotika yang ditahan di dalam Lapas. Ini tentu perlu mendapat perhatian, karena dikhawatirkan akan terjadi over capacity dan justru akan menambah subur penyalahgunaan dan peredaran gelap Narkotika di Indonesia. Berkaca dari pengalaman Amerika Serikat pada tahun 1960-an yang mengalami hal serupa seperti yang terjadi di Indonesia saat ini. Maka sudah sepatutnya, penerapan program TAT, konsep Rehabilitasi dan Dekriminalisasi Penyalahguna Narkotika di Indonesia harus lebih ditingkatkan.

\section{SIMPULAN}

1. Faktor-faktor yang memengaruhi
efektivitas pelaksanaan program TAT diantaranya adalah Sosialisasi Program TAT, Pemahaman Program TAT Oleh Anggota Tim TAT (Medis dan Hukum), Tujuan Program TAT, Ketepatan Sasaran dari Program TAT serta Perubahan Nyata setelah Program TAT telah dilaksanakan. Berdasarkan penelitian ini, penulis juga mencoba mengajukan faktor lain, yakni Koordinasi.

2. Walaupun pelaksanaan program TAT di BNN Jakarta Selatan melebihi target yang telah ditentukan, namun dalam pelaksanaannya masih dinilai kurang efektif. Hal tersebut terlihat dari masih banyaknya pecandu Narkotika yang mendapat vonis pidana penjara.

3. Perlu adanya sosialisasi lebih mendalam terkait program TAT, baik kepada tim TAT (Penyidik, Jaksa dan Dokter) maupun kepada masyarakat umum.

4. Hakim sebagai penentu vonis, juga perlu mendapat sosialisasi mengenai konsep Rehabilitasi dan Dekriminalisasi Penyalahguna Narkotika.

\section{DAFTAR PUSTAKA}

BNN dan Puslitkes UI. (2018). Survei Nasional Penyalah guna Narkoba tahun 2017. Jakarta.

Darmawel. (2018). Bahan Materi ToT UNODC: Kebijakan tentang Narkotika dalam Rangka Persamaan Persepsi Aparat Penegak Hukum. Yogyakarta 18 Oktober 2018.

Deputi Rehabilitasi. (2017). Buku Saku Standar Pelayanan Rehabilitasi Bagi Pecandu Dan Korban Penyalahgunaan Narkoba. Badan Narkotika Nasional. Jakarta.

Diagnosis Gangguan Jiwa, Rujukan Ringkas PPDGJ-III dan DSM-V. Cetakan 2 - Bagian Ilmu Kedokteran Jiwa Fakultas Kedokteran Unika Atma Jaya. Jakarta.

Galinesia. Teori Efektivitas meneurut pendapat para pakar terpercaya. 2017. Dalam web file:///Volumes/HP\%20V178P/s2/arsip\%20jurnal/Teori\%20Efektivitas\%20Menurut $\% 20$ Pendapat\%20Para\%20Pakar\%20Terpercaya.webarchive. 
Herryanto. (2017). Aspek Hukum Asesmen Terpadu Bagi Pengguna dan Pecandu Narkotika dalam Perspektif Hukum Pidana Berdasarkan Hukum Positif di Indonesia. Universitas Pasundan. Bandung.

http://digilib.unila.ac.id/323/12/BAB\%20II.pdf. Diunduh pada tanggal 13 November 2018. https://www.galinesia.com/2017/11/teori-efektivitas-menurut-pendapat-para.html. diunduh pada tanggal 12 November 2018.

Kholik, Syaifullah, dkk. Faktor-Faktor Yang Mempengaruhi Penyalahgunaan Narkoba Pada Klien Rehabilitasi Narkoba Di Poli Napza Rsj Sambang Lihum dalam Jurnal Skala Kesehatan Volume 5 No. 1 Tahun 2014 diakses dari https://www.google.com/url?sa=t\&rct=j\&q=\&esrc=s\&source=web\&cd=5\&cad=rja\& uact=8\&ved=2ahUKEwikNC849XeAhWRV30KHchXChcQFjAEegQIBBAC\&url= http $\% 3 \mathrm{~A} \% 2 \mathrm{~F} \% 2 \mathrm{Fwww}$. jurnalskalakesehatanpoltekkesbjm.com\%2Findex.php\%2FJ SK\%2Farticle\%2Fdownload\%2F13\%2F26\%2F\&usg=AOvVaw04hSf3qBHeNkk2d OQH38E5. Diunduh tanggal 12 november 2018.

NCBI Journal. Insight, Motivation and Outcome in Drug Treatment for Offenders: A Review of the Recent Literature.2015. dalam web file:///Volumes/HP\%20V178P/s2/arsip\%

20jurnal/Teori\%20Efektivitas\%20Menurut\%20Pendapat\%20Para\%20Pakar\%20Terp ercaya.webarchive.

Peraturan Kepala Badan Narkotika Nasional Nomor 11 Tahun 2014 Tentang Tata Cara Penanganan Tersangka Dan/Atau Terdakwa Pecandu Narkotika Dan Korban Penyalahgunaan Narkotika Ke Dalam Lembaga Rehabilitasi. Jakarta.

Peraturan Kepala Nomor 11 Tahun 2014 tentang Tata Cara Penanganan Tersangka dan/atau Terdakwa Pecandu Narkotika dan Korban Penyalahgunaan Narkotika Ke Dalam Lembaga Rehabilitasi.

Peraturan Bersama tentang Penanganan Pecandu Narkotika Dan Korban Penyalahgunaan Narkotika Ke Dalam Lembaga Rehabilitasi tahun 2014.Jakarta.

Surat Edaran Mahkamah Agung Nomor 04 Tahun 2010. Jakarta.

Survei Nasional Penyalahgunaan Narkoba di 34 Provinsi Tahun 2017. BNN. Jakarta.

Surat Edaran Mahkamah Agung Nomor 4 Tahun 2010 tentang Penempatan Penyalahgunaan, Korban Penyalahgunaan dan Pecandu Narkotika Ke Dalam Lembaga Rehabilitasi Medis dan Rehabilitasi Sosial.

Undang-Undang Nomor 35 tahun 2009 tentang Narkotika. dalam Deputi Bidang Hukum dan Kerjasama Direktorat Hukum. 2016. Himpunan Peraturan tentang Narkotika dan peraturan lainnya. Badan Narkotika Nasional. JakartaUNODC. 2018.

Shafdggdghgdggadhgagaggagdhja.ffgg(2009).vgsahjahhahhagahghjagh. 